\title{
Perancangan Performansi Quality Of Service Dengan Metode Virtual Routing Redudancy Protocol (VRRP)
}

\author{
Mugi Raharjo ${ }^{1}$, Frengki Pernando ${ }^{2}$, Ahmad Fauzi ${ }^{3}$ \\ ${ }^{1}$ STMIK Nusamandiri Jakarta \\ e-mail: mugimou@gmail.com \\ ${ }^{2}$ STMIK Nusamandiri Jakarta \\ e-mail: 14002136@nusamandiri.ac.id \\ ${ }^{3}$ STMIK Nusamandiri Jakarta \\ e-mail: demore.band@gmail.com
}

Cara Sitasi: Raharjo, M., Pernando , F., \& Fauzi, A. (2019). Perancangan Performansi Quality Of Service Dengan Metode Virtual Routing Redudancy Protocol (VRRP). Jurnal Teknik Komputer, 87-92. doi:10.31294/jtk.v4i2

\begin{abstract}
The need for a network is the intenet is indeed already is common at this time. Do a computerized system in each routine office as well as the occurrence of problems in computer networks in a company can make the effectiveness and flexibility in an agency or company became very disturbed. In PT. PELITA Cengkareng, Tangerang Paper needs a stable internet network is the key to a company's main activity is to do every day. For it is need for a change in the system of internet network. To support all activities in the company who need access to a computer network or the internet. A stable traffic as well as the existence of a performance bond that was always adequate internet desperately needed in an era as it is today. For that VRRP (Virtual Routing Protocol Redudancy) is the solution to increase network performance can be done by the existence of this method. The existing network of companies will have a backup connectivity to backup when there are problems at the major networks.
\end{abstract}

Keyboard : Performancy, Netowork, Monitoring, Redudancy

\section{PENDAHULUAN}

Performa yang baik sangat dibutukan oleh setiap instansi atau perusahaan.Performa yang baik akan menentukan bagaimana nantinya sebuah instansi atau perusahaan tersebut akan semakin maju dan berkembang. Berbicara mengenai performa, Sebuah instansi atau perusahaan pasti mempunyai yang namanya Jaringan Komputer. Karena Jaringan merupakan suatu hal pokok yang harus ada pada sebuah instansi atau perusahaan, karena dengan jaringan dapat mempermudah kita dalam hal pertukaran data maupun transfer data. Untuk itulah performa pada sebuah jaringan komputer pada suatu instansi atau perusahaan haruslah mempunyai performa atau kualitas yang sangat baik dalam hal berkomunikasi dan pertukaran data informasi. Sebagai salah satu perusahaan yang bergerak di bidang percetakan dan memiliki kantor cabang, PT. Pelita Cengkareng Paper Tangerang tidak lepas dari kebutuhan penggunaan media internet sebagai media komunikasi data. Tentunya dalam penyaluran data dibutuhkan suatu sistem yang dapat berjalan efektif dengan mengurangi atau mencegah putusnya koneksi dalam sebuah jaringan komputer. Karena apabila terjadi masalah pada koneksi jaringan dapat menyebabkan kehilangan data yang dapat merugikan perusahaan dalam segi waktu,kinerja dan biaya

\section{METODOLOGI PENELITIAN}

Metode yang digunakan yaitu dengan 2 cara. Metode analisa penelitian sebagai berikut: Analisis, Kebutuhan,Desain,Perancangan,Testing. Sedangkan metode pengumpulan data sebagai berikut Observasi, Wawancara, Study Pustaka. Penelitian yang dilakukan penulis dalam menyusun jurnal ini yaitu menganalisa tentang jaringan yang berada pada PT. Pelita Cengkareng Paper Tangerang, serta memberikan suatu perancangan jaringan usulan yang lebih baik dengan menggunakan konsep Virtual routing redundancy Protocol (VRRP) dan konsepkonsep Firewall yang diterapkan untuk menjadikan jaringan di perusahaan tersebut menjadi lebih baik, mulai dari konfigurasi,Pada metode ini nantinya sebuah jaringan yang mempunyai perangkat yang digunakan sampai kepada manfaat atau kegunaan dari sistem tersebut, pada usulan jaringan ini penulis akan menggunakan topologi star.

Pada pembahasan VRRP ini penulis mengacu terhadap penelitian yaitu "VRRP bekerja dengan mengelompokan router secara bersamaan untuk menjadi satu route virtual dan menggunakan IP 
Address sendiri . VRRP merupakan protokol yang secara dinamis menunjukan satu atau lebih virtual router menjadi gateway router didalam jaringan LAN oleh (Trinanda \& Sulistyo, 2014) yang bertujuan untuk memungkinkan beberapa router di multiaccess link untuk menggunakan virtual ip address yang sama. Protokol routing redundancy telah dikembangkan untuk menyediakan perlindungan terhadap host jika terjadi kegagalan pada router. Penyedia layanan internet Maudy Network Komunikasi menyatakan bahwa kestabilan komunikasi sangat diutamakan, karena kestabilan komunikasi menciptakan kenyamanan dalam bertukar informasi. Hingga saat ini Maudy Network Komunikasi memiliki jaringan yang kompleks. Salah satunya, di dalam jaringan tersebut terdapat Virtual Local Area Network . Pembangunan jaringan yang kompleks dengan akurasi kestabilan komunikasi tinggi dilakukan dengan mengimplementasikan Virtual Router Redundancy Protocol (VRRP). VRRP menjaga dari terputusnya jalur komunikasi dan menjaga dari matinya router utama. Hal tersebut dikarenakan protokol VRRP menggunakan dua router yang berfungsi sebagai router master dan router backup.(Choirullah, Anif, \& Rochadi, 2016).

Menurut (Iriansyah \& Chandra, 2017:10) Quality of Service sebenarnya merupakan suatu hal yang sederhana pada jaringan, namun pada kenyataanya Quality of Service merupakan salah satu hal yang paling tidak diperhatikan. Permasalahan kongesti seringkali dianalogikan kepada permasalahan bandwidth, dan dijawab dengan peningkatan bandwidth.

Menurut (Madcoms, 2013:1) Jaringan komputer (computer Network) dapat diartikan sebagai sekelompok komputer yang dihubungkan menggunakan media tertentu sehingga antara komputer dapat saling berhubungan untuk berbagi data, informasi, program aplikasi, dan perangkat keras, seperti printer, scanner, CD/DVD Driver, ataupun hardisk. secara umum jaringan komputer terbagi menjadi 3 jenis, yaitu:

\section{Local Area Network}

Local Area Network adalah jaringan yang dibatasi oleh area yang relative kecil. Jaringan jenis ini biasanya menghubungkan antar-komputer satu dengan lainnya atau bisa juga node satu dengan node lainnya. Daerah jangkauan LAN tidaklah terlalu jauh, missal dalam suatu ruangan atau satu area dengan radius antara $100 \mathrm{~m}$ sampai $2.000 \mathrm{~m}$, tergantung dari jenis kabel yang digunakan.

\section{Metropolitan Area Network}

Jaringan komputer yang memiliki area lebih besar dari LAN, biasanya antar wilayah dalam satu propinsi. Jaringan MAN menghubungkan beberapa buah jaringan kecil ke dalam lingkungan area yang lebih besar. Jika suatu instansi atau perusahaan memiliki cabang dalam kota atau provinsi dangan jarak antara 10-50 km, dan setiap cabang saling berhubungan untuk bertukar data dan informasi, maka jaringan ini disebut jaringan MAN.

3. Wide Area Network(WAN)

Jaringan Komputer jenis ini merupakan gabungan dari kedua jenis jaringan di atas, yang telah mengalami pengembangan infrastruktur jaringan sehingga jarak cakupannya semakin jauh yaitu dunia. Manajemen jaringan adalah kemampuan untuk mengontrol dan memonitor sebuah jaringan komputer dari sebuah lokasi.

Berikut model konseptual menjelaskan fungsi manajemen jaringan:

1. Manajemen kesalahan Menyediakan fasilitas yang memungkinkan administrator jaringan untuk mengetahui kesalahan pada perangkat yang di kelola.

2. Manajemen konfigurasi Memonitor informasi konfigurasi jaringan sehingga perangkat keras dan perangkat lunak dapat dikelola dengan baik.

3. Manajemen keamanan Mengatur akses ke sumber daya jaringan sehingga tidak dapat di peroleh tanpa izin. Di dalam konsep penunjang usulan penulis menggunakan konsep Virtual Roter Redundancy Protocol (VRRP) yang dikutip dari.

Dengan virtualisasi, dapat diperoleh utilitas yang lebih besar dari komponen fisik yang tersedia. VRRP merupakan protokol virtual router yang bertanggung jawab menjalankan fungsi router backup saat kondisi router master mengalami kegagalan di jaringan LAN. VRRP merupakan standar dari IEEE dan bersifat open source. VRRP dapat diaplikasikan menggunakan framework sistem operasi apapun, di antaranya Linux, Sun Solaris, dan Mikrotik. VRRP juga mendukung berbagai platform jaringan yang berbeda, seperti Multi Packet Label Switch (MPLS), Virtual Private Network (VPN), $V L A N$, maupun yang lainnya.(Choirullah et al., 2016)

\section{HASIL DAN PEMBAHASAN}

\section{Topologi Jaringan}

Jaringan komputer yang sedang berjalan pada PT. Pelita Cengkareng Paper yaitu menggunakan kabel UTP , Fiber Optic dan sebagian jaringan wireless. Jaringan komputer ini digunakan untuk melayani seluruh kegiatan dalam lingkungan PT. Pelita Cengkareng Paper dalam mengakses Jaringan local ,jaringan internet, pertukaran data, surat elektronik (email), pencarian informasi di website melalui browser, dan lain-lain.Jaringan komputer pada PT. Pelita Cengkareng Paper sendiri memiliki beberapa jaringan yaitu jaringan pada kantor unit Jakarta dan 
jaringan pada unit cabang. Topologi yang digunakan pada PT. Pelita Cengkareng Paper adalah topologi Star karena memanfaatkan switch,hub,router dan wirelless sebagai penghubung antara gedung satu dan yang lainnya dan juga sebagai penghubung koneksi jaringan antara jaringan utama dan client. Jaringan komputer yang sedang berjalan pada PT. Pelita Cengkareng Paper yaitu menggunakan kabel UTP , Fiber Optic dan sebagian jaringan wireless. Jaringan komputer ini digunakan untuk melayani seluruh kegiatan dalam lingkungan PT. Pelita Cengkareng Paper dalam mengakses Jaringan lokal ,jaringan internet, pertukaran data, surat elektronik (email), pencarian informasi di website melalui browser, dan lain-lain.Jaringan komputer pada PT. Pelita Cengkareng Paper sendiri memiliki beberapa jaringan yaitu jaringan pada kantor unit Jakarta dan jaringan pada unit cabang. Topologi yang digunakan pada PT. Pelita Cengkareng Paper adalah topologi Star karena memanfaatkan switch,hub,router dan wirelless sebagai penghubung antara gedung satu dan yang lainnya dan juga sebagai penghubung koneksi jaringan antara jaringan utam dan client.

Tabel 1 Spesifikasi software jaringan

\begin{tabular}{|c|c|c|c|}
\hline NO & Jenis Perangkat & $\begin{array}{c}\text { Nama } \\
\text { Perangkat }\end{array}$ & Tipe \\
\hline 1 & Operating System & $\begin{array}{l}\text { Windows } 7 \\
\text { Pro } \\
\text { Windows } \\
\text { Server } \\
2008\end{array}$ & Licensed \\
\hline 2 & Browser & $\begin{array}{l}\text { Mozila } \\
\text { Firefox }\end{array}$ & \\
\hline 3 & Anti Virus & $\begin{array}{l}\text { Avast } \\
\text { SOPHOS }\end{array}$ & $\begin{array}{l}\text { Free } \\
\text { Licensed }\end{array}$ \\
\hline 4 & Software Transfer & FilleZilla & $\begin{array}{l}\text { Open } \\
\text { Source }\end{array}$ \\
\hline 5 & Design Networking & $\begin{array}{l}\text { Cisco } \\
\text { Packet } \\
\text { Tracer }\end{array}$ & Free \\
\hline 6 & Office Soft & $\begin{array}{l}\text { Microsoft } \\
\text { Office } \\
2007\end{array}$ & Licensed \\
\hline 7 & Software File & WinRar & Free \\
\hline
\end{tabular}


Gambar 1. Skema Jaringan Kantor Pusat Berjalan

Sumber internet pada skema jaringan usulan di atas adalah menggunakan ISP yang sudah ada sebelumnya yaitu dari icon+ dimana masing- masing gedung memiliki IP Address yang didapat dari router mikrotik di ruang IT. Lalu di usulan ini diberikan tambahan berupa ISP baru,Tujuannya adalah sebagai backup koneksi agar beban yang ada di ISP utama tidak terlalu berat sehingga sebagian komputer yang terdapat di PT.Pelita Cengkareng Paper bisa menggunakan ISP baru terebut. ISP baru ini juga bertugas sebagai backup untuk alternative koneksi internet apabila ISP utama bermasalah

\section{Keaman Jaringan}

Sistem keamanan pada system PT.Pelita Cengkareng Paper Tangerang. Penulis memberikan usulan firewall berupa filtering untuk beberapa situs,Fungsinya untuk meminimalisir penggunaan bandwitdh yang besar pada saat jam- jam kerja berlangsung sehingga tidak menggangu aktifitas atau kinerja jaringan internet.

Secara umum, firewall filtering biasanya dilakukan dengan cara mendefinisikan IP address, baik itu srcaddress maupun dst-address. Misalnya Anda ingin blok komputer client yang memiliki IP tertentu atau ketika melakukan blok terhadap web tertentu berdasarkan IP web tersebut. Firewall tidak hanya digunakan untuk melakukan blok client agar tidak dapat mengakses resource tertentu, namun juga digunakan untuk melindungi jaringan local dari ancaman luar, misalnya virus atau serangan hacker. Biasanya serangan dari internet ini dilakukan dari banyak IP sehingga akan sulit bagi kita untuk melakukan perlindungan hanya dengan berdasarkan IP. Nah, sebenarnya ada banyak cara filtering selain berdasar IP Address, misalnya berdasar protocol dan port. Berikut contoh implementasi dengan memanfaatkan beberapa parameter di fitur firewall filter.

\section{Rancangan Aplikasi}

Konfigurasi yang akan dilakukan untuk penerapan metode VRRP (Virtual Routing Redudancy Protocol). Berikut adalah skema VRRP pada router mikrotik di kantor pusat maupun kantor cabang mikrotik ini berfungsi sebagai perangkat yang mengatur keseluruhan aktifitas jaringan.

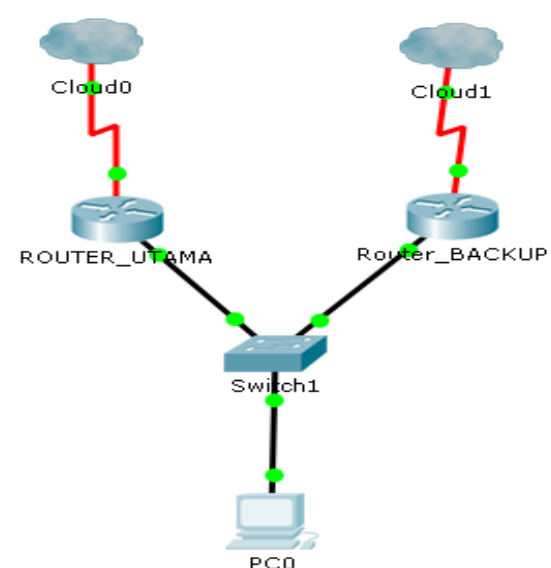

Sumber: Hasil Penelitian

\section{Gambar 2. Skema VRRP}

VRRP (Virtual Router Redundancy Protocol) merupakan sebuah interface (virtual) dari RouterOS MikroTik yang memungkinkan kita untuk membuat beberapa router sebagai gateway dari jaringan lokal yang satu segment. Komunikasi antar router akan menggunakan sebuah Virtual Router ID dan pada interface VRRP dimasing- masing router akan dIPasang sebuah single IP Address yang nantinya akan digunakan sebagai gateway dari jaringan lokal tersebut. Karena ada beberapa router yang menjadi gateway dari satu jaringan lokal, maka kita bisa juga melakukan sebuah 'Prioritas'. Dengan kata lain ada satu router yang bisa dijadikan sebagai gateway utama dan yang lain akan menjadi backup. Seperti halnya mekanisme dari 'Fail Over' jika jalur dari gateway utama putus maka bisa di-cover oleh jalur yang lain. Hal ini mungkin cukup membantu jika pada suatu saat ketika gateway utama bukan hanya jalur nya saja yang putus namun juga mengalami kerusakan pada perangkat dan dengan segera akan bisa di-backup oleh perangkat yang lain tanpa kita perlu melakukan konfigurasi baru dari router tersebut.

Konfigurasi Router Primary :

Sumber: Hasil Penelitian

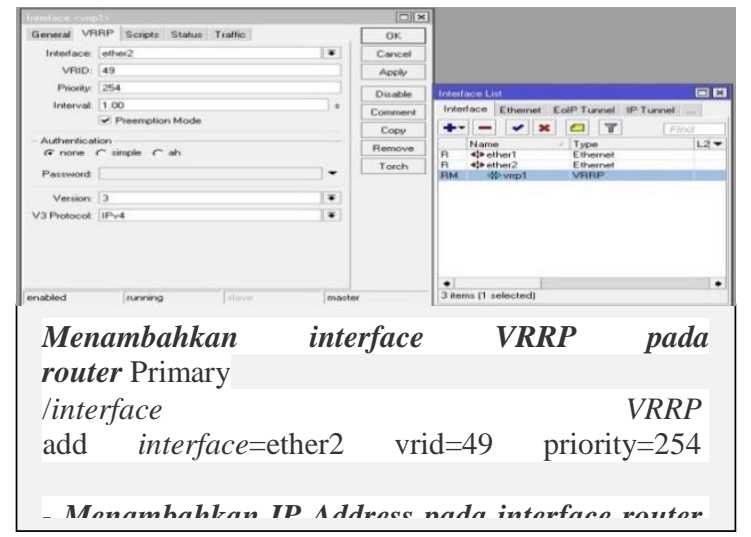

Gambar 3. Setting VRRP Router Primary 
Konfigurasi VRRP Router Backup :

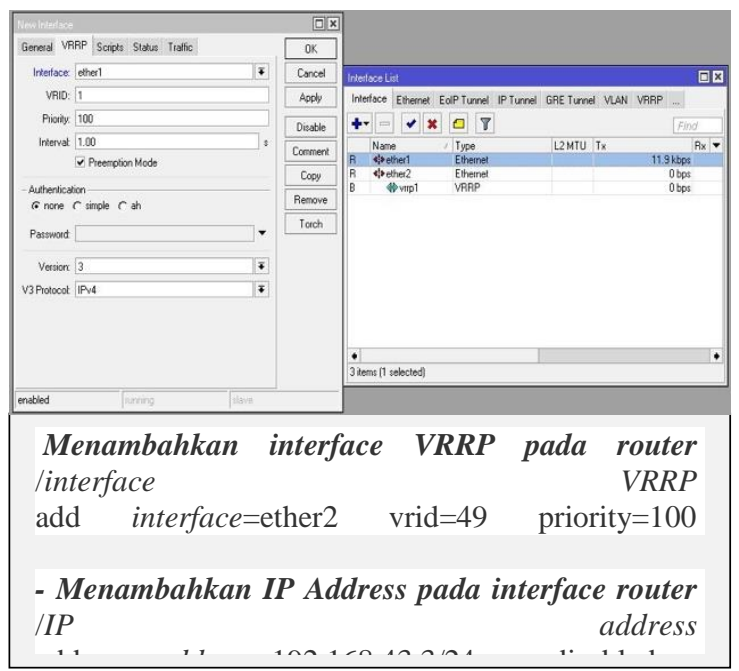

Sumber: Hasil Penelitian

Gambar 4. Setting VRRP Router Backup

Perlu diketahui untuk konfigurasi interface VRRP pada masing-masing router, pada parameter Virtual Router ID (vrid) harus disamakan nilainya. Kemudian pada parameter 'Priority', untuk router sebagai gateway utama kita setting dengan nilai yang lebih tinggi darIPada router backup. Dan kita juga harus menambahkan sebuah Single IP Address (dengan prefix /32) pada interface VRRP di masingmasing router yang berfungsi sebagai default gateway dari client di jaringan lokal.

\section{Pengujian Jaringan}

a. Pengujian Awal

Pada tahap pengujian jaringan awal Penulis melakukan pengujian terhadap client dalam situasi dimana pada saat melakukan testing Ping dari client ke jaringan internet, Tiba-tiba router mati atau bermasalah sehingga terjadilah koneksi antara client serta seluruh jaringan yang ada menjadi terputus.

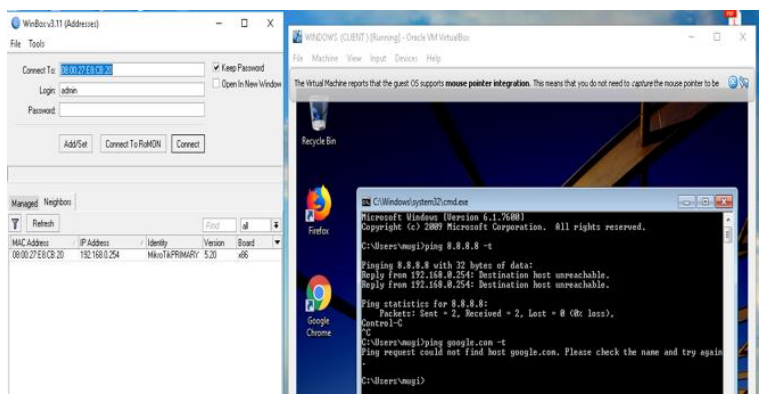

Sumber: Hasil Penelitian

Gambar 5. Test Ping sebelum memakai VRRP

Hasil seperti diatas tidak akan terjadi apabila kita sudah menggunakan metode Virtual Routing
Redundancy Protocol (VRRP). Untuk pengujian terhadap metode VRRP ,Penulis akan membuktikan metode VRRP yang sudah digunakan pada sub bab sealanjutnya yaitu pengujian jaringan akhir.

\section{b. Pengujian Jaringan Akhir}

Pada tahap pengujian jaringan awal dilakukan pada metode VRRP adalah melakukan Ping test.

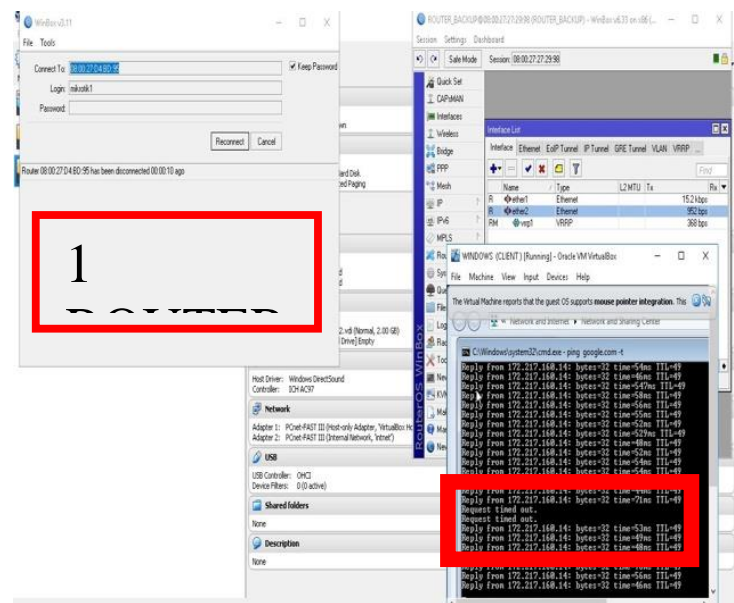

Sumber: Hasil Penelitian

Gambar 6. Test Ping Cabang-Pusat (sesudah)

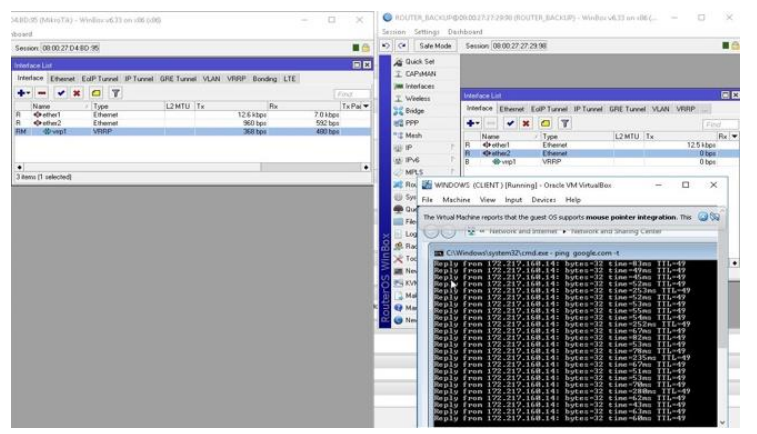

Sumber: Hasil Penelitian

Gambar 7. Test Ping sebelum router di matikan

Pada tahap uji perancangan ini Penulis melakukan test uji ketika router pertama dimatikan secara otomatis router kedua membackup router yang mati tersebut sehingga akses jaringan yang tersedia di Perusahaan bisa terbackup. Hasil uji ping yang Penulis lakukan menunjukkan bahwa pada saat router utama mati terjadi beberapa RTO (Request timed out) sebanyak dua kali, Selanjutnya jaringan kembali berjalan normal. Hal ini sangat berarti jika kita tidak memakai metode VRRP maka sangatlah mungkin ketika user sedang mengirimkan suatu data bisa tersendat atau bahkan gagal karena jaringan internet yang mati. Untuk itu dengan adanya VRRP ini sangat 


\section{KESIMPULAN}

Setelah melakukan analisa jaringan komputer pada PT Pelita Cengkareng Paper Tangerang maka dapat disimpulkan bahwa, Sistem jaringan yang ada menggunakan topologi star dan untuk kebutuhan internet menggunakan ISP (Internet Service Provider) dari Icon+. Untuk pertukaran data menggunakan media transfer file dengan sharing folder dan juga sudah mempunyai mail server untuk melakukan pengiriman pesan via email. Kebutuhan akan akses internet yang tinggi demi mendukungnya kinerja karyawan,maka dari itu dibutuhkan Quality Of Service dari jaringan computer yang ada.Untuk itu dibutuhkanlah sebuah metode yang bisa membantu kinerja sebuah jaringan menjadi lebih baik lagi.

\section{REFERENSI}

Choirullah, M. Y., Anif, M., \& Rochadi, A. (2016). Analisis Kualitas Layanan Virtual Router Redundancy Protocol Menggunakan Mikrotik pada Jaringan VLAN. Jnteti, 5(4), 278-285.

Ilmiah, A. (2017). Penerapan Virtual Router Redundancy Protocol Pada Mikrotik Berbasis IPv6 Untuk Meningkatkan Performansi Quality Of Service Program Studi Teknik Informatika Fakultas Teknologi Informasi Universitas Kristen Satya Wacana Penerapan Virtual Router Redundancy P, (672010046).

Trinanda, Y. D. P., \& Sulistyo, W. (2014). Analisis Kinerja Protocol Redundancy Hot Standby Router Protocol (HSRP) dan Virtual Redundancy Protocol (VRRP), 11-28.

Madcoms. 2013. Cepat Dan Mudah Membangun Sistem Jaringan Komputer. Yogyakarta: CV. Andi Offset.

\section{PROFIL PENULIS}

1. Mugi Raharjo

Lahir di Jakarta 29 Agustus 1995 , berpendidikan terakhir meraih gelar Sarjana Komputer pada tahun 2017 di Program STMIK Nusamandiri Jakarta dan sedang melanjutkan studi Pasca Sarjana Ilmu Komputer, bekerja sebagai Instruktur Komputer pada Program Studi Sistem Informasi STMIK Nusamandiri jakarta.

2. Frengki Fernando

Lahir di Berebes 29 Mei 1995, berpendidikan terakhir meraih gelar Sarjana Komputer pada tahun 2017 di Program STMIK Nusamandiri Jakarta dan sedang melanjutkan studi Pasca Sarjana Ilmu Komputer, bekerja sebagai Instruktur Komputer pada Program Studi Sistem Informasi STMIK Nusamandiri jakarta.

3. Ahmad Fauzi

Lahir di Bekasi 4 April 1990, berpendidikan terakhir meraih gelar Master Komputer pada tahun 2016 di Program Pasca Sarjana STMIK Nusamandiri Jakarta dan bekerja sebagai Dosen Program Studi Sistem Informasi STMIK Nusamandiri jakarta. 